\title{
Pregnancy Readiness in Married Female Adolescents from Different Ethnic Groups in Probolinggo District, Indonesia
}

\section{Sri Sumarmi}

Universitas Airlangga Fakultas Kesehatan Masyarakat

Agung Dwi Laksono ( $\nabla$ agung.dwi.laksono-2016@fkm.unair.ac.id )

Badan Penelitian dan Pengembangan Kesehatan Kementerian Kesehatan Republik Indonesia https://orcid.org/0000-0002-9056-0399

\section{Research article}

Keywords: adolescent health, nutrition status, maternal health, pregnant adolescents, ethnicity

Posted Date: October 6th, 2020

DOI: https://doi.org/10.21203/rs.3.rs-85432/v1

License: @ (i) This work is licensed under a Creative Commons Attribution 4.0 International License. Read Full License 


\section{Abstract}

Background: Physical readiness for pregnancy potentially affects the new born's health status. The study aims to analyze pregnancy readiness in married female adolescents.

Methods: Data were collected in Probolinggo District, Indonesia from 2012-2014. This study involved 760 married female adolescents (<20 years old) as the analysis units. There are 2 major ethnic groups in Probolinggo District (Javanese and Madurese), as well as a small number of other ethnic groups. The study's dependent variable was pregnancy readiness, while its independent variable was ethnicity. In addition, other independent variables were also analyzed, for example, marital status, age, education, and employment. The final analysis was done using a binary logistic regression. Pregnancy readiness variable was seen from other sub-variables, such as anemia status, body weight, stature, nutritional status, and mid-upper-arm circumference.

Results: Married female adolescents mostly suffered from anemia. The respondents mostly had normal anthropometry. Regarding pregancy readiness variable, married female adolescents from all ethnicities married female adolescentswere not ready to get pregnant. Madurese married female adolescents were 0.563 times readier to get pregnant compared to Javanese married female adolescents (OR $0.563 ; 95 \% \mathrm{Cl} 0.369-0.857)$. There was no significant difference between Madurese ethnic adolescents and the Java-Madurese ones and others. Moreover, there was no significant difference between educational levels and the respondents' readiness for pregnancy.

Conclusions: There were partial differences in readiness for pregancy in married female adolescents from different ethnic groupsmarried female adolescents. Madurese married female adolescents had a lower possibility of prenancy readiness than Javanese ones.

\section{Background}

Early marriage still exists as part of traditional practices in several developing countries around the world, including Indonesia $(1,2)$. Many factors can affect it, for example, poverty and low educational levels (2-4). In general, early marriage has been associated with increased fertility and reduce the use of modern contraceptive, less frequent antenatal care, and unsafe delivery (5).

Early marriage is not only related to female adolescents' health, but also their conception. Mostly, female adolescents are not ready enough to get married. Those who conceive need prime nutrition for their baby. Married female adolescents undernutrition will get worse during pregnancy. A malnourished woman is more likely to deliver a malnourished baby, causing the cycle of malnutrition from generation to generation $(6,7)$. Previous studies provide evidence that pregnancy in married female adolescents married female adolescentsis a risk factor for early childhood development issues and stunting (5). married female adolescentslt also increases the risk of infant and child morbidity and mortality $(8,9)$.

In Indonesian, early marriage stems from the community's religious and cultural beliefs $(10,11)$. According to Statistics Indonesia in 2015 , the rate of early marriage in East Java was higher than the overall national rate, around 35\%. The number of early marriage is distributed mainly in the northeast region of East Java province. The Probolinggo district has the highest rate of early marriage among other regencies/municipals of East Java (12). Previous research in this region reveals that $23 \%$ of reproductive-age women were underweight, $33 \%$ had anemia, and $15.7 \%$ were diagnosed with iron deficiency (13).

Based on the results of literature searching, previous research publications rarely analyze pregnancy readiness among married female adolescents from the aspects of physical readiness, anemia status and anthropometric status. Based on this reason, this study was aimed at analyzing pregnancy readiness among married female adolescents from different ethinic groups in Probolinggo, Indonesia.

\section{Methods}

\section{Data Source}

This study was conducted by collecting primary data in Probolinggo district, East Java, Indonesia. Data collection was carried out in a multi-round survey from 2012-2014. The study's analysis unit was female adolescents (< 20 years) who were married. There were 2,493 newly married couples registered in nine selected sub-district offices of religious affairs between 2012 and 2014. Only non-pregnant women were enrolled to minimize the gestational effects on hemoglobin and anthropometric indices. Pregnancy testing was performed using the urinary-human chorionic gonadotropin (hCG) test kits from OneMed ${ }^{\circledR}$ products. The final sample size was 760 respondents that matched the inclusion criteria.

\section{Data Analysis}

This study firstly disccusses about pregnancy readiness as the dependent variablemarried female adolescents. Pregnancy readiness was determined from anemia status seen from the levels of hemoglobin and anthropometric status. Anthropometric status consisted of body weight, stature, nutritional status based on body mass index (BMI), and mid-upper arm circumference (MUAC). Married female adolescents were considered ready to get pregnant if they do not suffer from anemia, underweight $(\leq 40 \mathrm{~kg})$, and, short stature $(\leq 140 \mathrm{~cm})$. Besides, they should have the MUAC of $\geq 23.5 \mathrm{~cm}$.

The levels of hemoglobin were determined from capillary finger-prick blood samples drawn using HemoCue Hb 201 micro cuvettes and subsequently analyzed using a portable hemoglobin measurement kit, HemoCue ${ }^{\circledR}$ AB, from Anglehome, Sweden. Anemia was classified into four categories according to the WHO: mild anemia (hemoglobin level of 10-11.9 g/dL), moderate anemia (hemoglobin level of 7-10 g/dL), and severe anemia (hemoglobin level of < $7 \mathrm{~g} / \mathrm{dL}$ ) (14). Bodyweight was measured using a digital body scale Seca ${ }^{\circledR}$ type 803 with an increment of $100 \mathrm{~g}$. Furthermore, body stature was measured using a microtoise with a $0.1 \mathrm{~cm}$ increment. BMI was calculated as a ratio of weight in kilograms and the square of height in meters (kg/m2). Age-specific BMI reference values for adolescence were used to evaluate the nutrition status of subjects aged 14-19 years (15). Underweight in adolescents was described as BMI with the standard deviations (SD) of <-2. Overweight in adolescents was described as BMI with the SD of $>+2$. Obesity in adolescents was described as 
BMI with the SD of $>+3$. Measurement of MUAC was performed using a fiber tape with a $0.1 \mathrm{~cm}$ increment. A cut-off point of $<23.5 \mathrm{~cm}$ denoted a risk for chronic energy deficiency (16). All anthropometric measurements were performed by well-trained field staffs.

Despite ethnicity, there were four other independent variables involved: marital status, age, education level, and employment status. Ethnicity consists of three categories: Javanese, Madurese, and others. Marital status consisted of two categories: first married and second marriage/more. Age was the age of female adolescents at the lastest marriage. Age was grouped into three groups: $\leq 15$ years old, $16-17$ years old, and $\geq 18$ years old. Education level consisted of four levels: no school, elementary school, junior high school, senior high school, and higher. Employment status was categorized into two: unemployed and employed.

In the initial stage, a collinearity test was carried out to ensure whether there was no collinearity between variables. Because all variables were dichotomous, the next step was to use the chi-square test to select the dependent variable for the next testing stage. The nature of the dependent variable, in the final stage, utilized a binary logistic regression test to determine predictors of the nutritional status of married female adolescents. All statistical analyzes were carried out using SPSS 22 software.

\section{Results}

Table 1 shows the distribution of anemia status and anthropometric status among married female adolescents in Probolinggo district, Indonesia. The number of respondents with anemia was slightly greater than those without anemia. Those with normal body weight and normal stature were dominant. Most of the respondents had normal nutritional status and MUAC of $\geq 23.5 \mathrm{~cm}$.

Tabel 1. Frequency distribution of anemia status and anthropometric status among married adolescent girls in Probolinggo Regency, Indonesia $(n=760)$

\begin{tabular}{|lll|}
\hline Variable & $\mathbf{n}$ & $\%$ \\
\hline Anemia status & & \\
\hline Severe anemia & 27 & $3.6 \%$ \\
\hline Moderate anemia & 77 & $10.1 \%$ \\
\hline Mild anemia & 291 & $38.3 \%$ \\
\hline Not anemia & 365 & $48.0 \%$ \\
\hline Bodyweight & & \\
\hline Low bodyweight & 116 & $15.3 \%$ \\
\hline Normal bodyweight & 644 & $84.7 \%$ \\
\hline Stature status & & \\
\hline Short stature & 88 & $11.6 \%$ \\
\hline Normal stature & 672 & $88.4 \%$ \\
\hline Nutritional status & & \\
\hline Underweight & 227 & $29.9 \%$ \\
\hline Normal weight & 463 & $60.9 \%$ \\
\hline Overweight & 57 & $7.5 \%$ \\
\hline Obese & 13 & $1.7 \%$ \\
\hline Mid-upper-arm circumference & & \\
\hline$<23.5$ cm & 264 & $34.7 \%$ \\
\hline$\geq 23.5$ cm & $65.3 \%$ \\
\hline
\end{tabular}

In Table 2, the results of the collinearity test show that the tolerance value of all variables was greater than 0.10 . While the VIF value for all variables was less than 10.00 . The basis for decision making in the multicollinearity test concludes that there were no symptoms of multicollinearity in the regression model.

Tabel 2. Colinearity test results of the readiness to get pregnant among married adolescent girls and related variables in Probolinggo Regency, Indonesia ( $\mathrm{n}=$ 760) 


\begin{tabular}{|lll|}
\hline Variables & \multicolumn{2}{l|}{ Collinearity Statistics } \\
\cline { 2 - 3 } & Tolerance & VIF \\
\hline Ethnicity & 0.985 & 1.016 \\
\hline Marital type & 0.978 & 1.023 \\
\hline Age groups & 0.939 & 1.065 \\
\hline Education level & 0.921 & 1.085 \\
\hline Employment status & 0.983 & 1.017 \\
\hline Dependent Variable: the readiness to get pregnant \\
\hline
\end{tabular}

Besides, Table 3 shows the cross-tabulation of ethnicity, pregnancy readiness, and related variables. The respondents in all ethnic groups were mostly not ready to get pregnant. In all ethnicities, most of the respondents had the first marriage and were in the age group of $\geq 18$, except for others ethnic dominated by those in the age group 16-17.

Tabel 3. Descriptive statistics of ethnicity, the readiness to get pregnant among married adolescent girls, and related variables in Probolinggo Regency, Indonesia $(n=760)$

\begin{tabular}{|c|c|c|c|c|c|c|c|}
\hline \multirow[t]{3}{*}{ Characteristics } & \multicolumn{6}{|c|}{ Ethnicity } & \multirow[t]{3}{*}{$\mathbf{P}$} \\
\hline & \multicolumn{2}{|c|}{ Javanese } & \multicolumn{2}{|c|}{ Madurese } & \multicolumn{2}{|c|}{ Others } & \\
\hline & $\mathbf{n}$ & $\%$ & $\mathbf{n}$ & $\%$ & $\mathbf{n}$ & $\%$ & \\
\hline Readiness to get pregnant & & & & & & & $\star 0.036$ \\
\hline - Not ready & 287 & $71.4 \%$ & 159 & $81.1 \%$ & 119 & $73.5 \%$ & \\
\hline - Ready & 115 & $28.6 \%$ & 37 & $18.9 \%$ & 43 & $26.5 \%$ & \\
\hline Marital type & & & & & & & 0.984 \\
\hline - First marriage (ref.) & 376 & $93.5 \%$ & 183 & $93.4 \%$ & 152 & $93.8 \%$ & \\
\hline - Second marriage/more & 26 & $6.5 \%$ & 13 & $6.6 \%$ & 10 & $6.2 \%$ & \\
\hline Age groups & & & & & & & 0.248 \\
\hline$-\leq 15$ (ref.) & 10 & $2.5 \%$ & 6 & $3.1 \%$ & 9 & $5.6 \%$ & \\
\hline$-16-17$ & 191 & $47.5 \%$ & 85 & $43.4 \%$ & 80 & $49.4 \%$ & \\
\hline$-\geq 18$ & 201 & $50.0 \%$ & 105 & $53.6 \%$ & 73 & $45.1 \%$ & \\
\hline Education level & & & & & & & $\star * 0.004$ \\
\hline - No school & 46 & $11.4 \%$ & 27 & $13.8 \%$ & 7 & $4.3 \%$ & \\
\hline - Elementary school & 141 & $35.1 \%$ & 53 & $27.0 \%$ & 46 & $28.4 \%$ & \\
\hline - Junior high school & 128 & $31.8 \%$ & 60 & $30.6 \%$ & 69 & $42.6 \%$ & \\
\hline - Senior high school and higher & 87 & $21.6 \%$ & 56 & $28.6 \%$ & 40 & $24.7 \%$ & \\
\hline Employment status & & & & & & & 0.779 \\
\hline - Unemployed & 198 & $49.3 \%$ & 95 & $48.5 \%$ & 84 & $51.9 \%$ & \\
\hline - Employed (ref.) & 204 & $50.7 \%$ & 101 & $51.5 \%$ & 78 & $48.1 \%$ & \\
\hline
\end{tabular}

Furthermore, Javanese respondents dominantly graduated from elementary school education. While Madurese and other respondents had junior high school education.

Based on employment status, Javanese and Madurese respondents were employed. While the respondents from other ethnic groups were dominantly unemployed.

Further results of the binary logistic regression test on pregancny readiness are available in Table 4. There were two independent variables tested at this stage: ethnicity and education level. 
The results of the analysis in Table 4 inform that Madurese married female adolescents were 0.563 times more likely to be ready for pregancy than Javanese married female adolescents (OR $0.563 ; 95 \% \mathrm{Cl} 0.369-0.857$ ). While no significant differences were found between the other ethnic groups and the Javanese group. Similarly, there were no significant differences between education levels.

Tabel 4. Binary logistic regression test results of the readiness to get pregnant among married adolescent girls in Probolinggo Regency, Indonesia $(n=760)$

\begin{tabular}{|lllll|}
\hline \multirow{2}{*}{ Predictors } & \multicolumn{4}{l}{ The readiness of Nutritional Status } \\
\cline { 2 - 5 } & Sig. & OR & Lower Bound & Upper Bound \\
\hline Ethnicity: Javanese & - & - & - & - \\
\hline Ethnicity: Madurese & $* * 0.007$ & 0.563 & 0.369 & 0.857 \\
\hline Ethnicity: Others & 0.717 & 0.926 & 0.611 & 1.403 \\
\hline Education level: No school & - & - & - & - \\
\hline Education level: Elementary school & 0.438 & 0.798 & 0.451 & 1.412 \\
\hline Education level: Junior high school & 0.157 & 0.660 & 0.371 & 1.174 \\
\hline Education level: Senior high school and higher & 0.848 & 1.059 & 0.590 & 1.899 \\
\hline Note: $* \mathrm{p}<0.05 ; * * \mathrm{p}<0.01 ; * * * \mathrm{p}<0.001$. & & & & \\
\hline
\end{tabular}

\section{Discussion}

Married female adolescents who are lack of pregnancy readiness are still found in some areas. The ongoing practice of early marriage (1)(10) and many reports on the high prevalence of anemic adolescents and nutritional status issues in young women (17-21) are two among other evidence in Indonesia (22).

The results of the analysis inform that Madurese married female adolescents were less likely to be ready for pregnancy than Java ethnic. The findings of this study reinforce the results of previous studies focusing on Madurese or areas dominated by Madurese ethnic group. Madurese in general still practice culture contrary to modern health practices $(23,24)$. For example, they adopt the different concept of family size and early marriage $(25)$ and rarely utilize health services (26).

The 2018 Indonesian Public Health Development Index (IPHDI) released by the Indonesian Ministry of Health shows places regencies/municipalities dominated by Madurese are at the lowest rank of public health index. The five lowest ranked regions on the public health index in East Java Province are mostly inhabited by Madurese population (27). This ranking shift in East Java over the years has not changed much compared to the previous IPHDI (28). Despite health issues, the Madurese group has inferior stereotypes compared to other ethnic groups in East Java province (29).

Although the bivariate analysis shows there is a significant relationship between the education level and ethnicity, there is no difference between education levels in predicting pregnancy readiness. This finding shows that different education levels among married female adolescents from different ethnic groups do not contirbute to give a significant impact on physical readiness for pregnancy. The results of this study are contradictory to some previous studies which found that education level was a positive predictor of many health outputs (30-32).

A previous systematic review found that better socioeconomic status, especially higher education, tends to have higher dietary scores, a greater consumption of fruits, vegetables, and dairy products, and lower consumption of sugar-sweetened beverages and energy-dense foods. While other lower education levels did not show a significant difference (33). The bivariate analysis shows that education level affected the choice of food consumed.

In a broader view, education levels of the female adolescents and young mothers are also closely related to nutritional status in adolescents. A study conducted in the Northwest Ethiopia discovers a close relationship between poor nutritional status in adolescents and poor education levels of their mothers. Mothers with low education level were 2.84 times more likely to have stunted or short children than mothers with higher education level (34). Similarly, another study in West Java, Indonesia foundmothers with lower education level were 1.19 times more likely to have short children compared to mothers with higher education level (35).

Previous studies in various countries inform that education level affected the anemia and nutritional status (36-38), including overweight status (39). A slight deviation was found in India where literacy, economic, and physical activity status were the most significant predictors that affected nutritional status. Specifically, differences in reading ability became the predictor of the nutritional status in adolescents, but education level did not (40).

\section{Conclusions}

It can be concluded that there were partial differences in pregnancy readiness between married female adolescents from different ethnicities in Probolinggo district, East Java, Indonesia. Madurese married female adolescents had a lower possibility being ready for pregnancy than Java ethnic group. Besides, other variables were not the predictors of pregnancy readiness among those married female adolescents.

\section{Declarations}


Ethics approval and consent to participate

This study has received ethical clearance from the Faculty of Medicine Gadjah Mada University, Yogyakarta, Indonesia (Number KE/FK/202/EC). In this study, an informed consent was used during data collection by considering the data collection procedures, voluntary participation, and confidentiality of respondents' profile. The parents or guardians of the adolescents have given a written consent for the adolescents' participation in this study. All respondents' identities have been removed from the dataset.

\section{Consent for publication}

Not applicable

\section{Availability of data and materials}

The datasets used and/or analyzed during the current study are available from the corresponding author on reasonable request.

\section{Competing interests}

The authors declare that they have no competing interests.

\section{Funding}

Not applicable.

\section{Authors' contributions}

SS analyzed the data and drafted the manuscript. ADL collected the samples and performed the experiments. SS and ADL conceived and designed the experiments and revised the manuscript. All authors read and approved the final manuscript

\section{Acknowledgments}

The author thanks the Government of Probolinggo Regency, East Java Province, Indonesia, for supporting the implementation of this research.

\section{References}

1. Harianja AJ. Early Marriage Rates in Indonesia Are Still High (Angka Pernikahan Dini di Indonesia Masih Tinggi) [Internet]. 2019 [cited 2020 Feb 4]. p. 1. Available from: https://www.idntimes.com/news/indonesia/axel-harianja/bkkbn-angka-pernikahan-dini-di-indonesia-masih-tinggi/full

2. Hennifebriawatia, Wulanangrainia, Yanuarti R, Yandrizal, Padila, Andrikusumawijaya, et al. Determinant fakctors of early marriage in Bengkulu Tengah. Pakistan J Med Heal Sci. 2019;13(1):202-5.

3. Bezie M, Addisu D. Determinants of early marriage among married women in Injibara town, north West Ethiopia: Community-based cross-sectional study. BMC Womens Health. 2019;19(1):Article number 134.

4. Hamed AF, Yousef FMA. Prevalence, health and social hazards, and attitude toward early marriage in ever-married women, Sohag, Upper Egypt. J Egypt Public Health Assoc. 2017;92(4):228-34.

5. Efevbera Y, Bhabha J, Farmer P, Fink G. Girl child marriage, socioeconomic status, and undernutrition: Evidence from 35 countries in Sub-Saharan Africa. BMC Med. 2019;17(1):Article number 55.

6. Prentice AM, Ward KA, Goldberg GR, Jarjou LM, Moore SE, Fulford AJ, et al. Critical windows for nutritional interventions against stunting. Am J Clin Nutr. 2013;97(5):911-918.

7. Workicho A, Belachew T, Ghosh S, Kershaw M, Lachat C, Kolsteren P. Burden and determinants of undernutrition among young pregnant women in Ethiopia. Matern Child Nutr. 2019;15(3):Article number e12751.

8. Efevbera Y, Bhabha J, Farmer PE, Fink G. Girl child marriage as a risk factor for early childhood development and stunting. Soc Sci Med. 2017;185:91101.

9. Paul P. Child marriage and its association with morbidity and mortality of children under 5 years old: evidence from India. J Public Heal. 2019;in press:in press.

10. Ahyani S. Religious Court Considerations for Early Marriage Marriage Dispensation Due to Pregnancy Outside Marriage (Pertimbangan Pengadilan Agama Atas Dispensasi Pernikahan Usia Dini Akibat Kehamilan Di Luar Nikah). J Wawasan Huk. 2016;34(1):1-7.

11. Imanugraha, S. H, Budisuari MA. Aiming for Bella Ends Early Marriage (Mengincar Si Bella Berujung Pernikahan Dini). Surabaya: Unesa University Press; 2016.

12. Statistics Indonesia. Delayed progress: Analysis of child age marriage data in Indonesia (Kemajuan yang tertunda: Analisis data perkawinan usia anak di Indonesia) [Internet]. Jakarta; 2015. Available from: https://www.unicef.org/indonesia/id/Laporan_Perkawinan_Usia_Anak.pdf

13. Sumarmi S, Puspitasari N, Handajani R, Wirjatmadi B. Underweight as a Risk Factor for Iron Depletion and Iron- Deficient Erythropoiesis among Young Women in Rural Areas of East Java, Indonesia. Malays J Nutr. 2016;22(2):219-32.

14. World Health Organization C for DC and P. Assessing the iron status of populations [Internet]. Second Edi. Geneva: World Health Organization; 2007. 1108 p. Available from: https://www.who.int/nutrition/publications/micronutrients/anaemia_iron_deficiency/9789241596107/en/ 
15. de Onis M, Onyango A, Borghi E, Siyam A, Nishida C, Siekmann J. Development of a WHO growth reference for school-aged children and adolescents. Bull World Heal Organ. 2007;85(9):660-7.

16. Gibson R. Principles of Nutritional Assessment. Oxford: Oxford University Press; 2005.

17. Tariku A, Belew AK, Gonete KA., Hunegnaw MT, Muhammad EA, Demissie GD, et al. Stunting and Its Determinants among Adolescent Girls: Findings from the Nutrition Surveillance Project, Northwest Ethiopia. Ecol Food Nutr. 2019;58(5):481-94.

18. Takele WW, Muche AA, Mekonnen ZA, Ambaw YF, Wagnew F. Undernutrition and its determinants among Ethiopian adolescent girls: A protocol for systematic review and meta-analysis. BMJ Open. 2019;9(5):Article number e026718.

19. Regasa RT, Haidar JA. Anemia and its determinant of in-school adolescent girls from rural Ethiopia: A school based cross-sectional study. BMC Womens Health. 2019;19(1):Article number 98.

20. Chattopadhyay A, Sethi V, Nagargoje VP, Saraswat A, Surani N, Agarwal N, et al. WASH practices and its association with nutritional status of adolescent girls in poverty pockets of eastern India. BMC Womens Health. 2019;19(1):Article number 89.

21. Jinghuan J, Hu Y, Li M, Chen J, Mao D, Li W, et al. Prevalence of anemia in chinese children and adolescents and its associated factors. Int J Environ Res Public Health. 2019;16(8):Article number 1416.

22. National Institute of Health Research and Development of The Indonesia Ministry of Health. The 2018 Indonesia Basic Health Survey (Riskesdas): National Report [Internet]. Jakarta; 2019. Available from:

http://labmandat.litbang.depkes.go.id/images/download/laporan/RKD/2018/Laporan\%7B\%5C_\%7DNasional\%7B\%5C_\%7DRKD2018\%7B\%5C_\%7DFINAI

23. Laksono AD. Stereotypes of Madurese Society (Masyarakat Madura dalam Stereotipe). In: Dyson L, editor. Shamans Positioning. Yogyakarta: Kanisius; 2014. p. 25-49.

24. Diana R, Rachmayanti RD, Anwar F, Khomsan A, Christianti DF, Kusuma R. Food taboos and suggestions among Madurese pregnant women: a qualitative study. J Ethn Foods. 2018;5(4):246-53.

25. Widyasari R, Sari ID, Maghfiroh AL, Haryanto S, Pramono MS. The 2012 Maternal and Child Health Ethnographic Series, Madura Ethnic Jrangoan Village, Omben District Sampang Regency, East Java Province (Buku Seri Etnografi Kesehatan Ibu dan Anak 2012, Etnik Madura Desa Jrangoan, Kecamatan Omben Kabupaten Sampang, Pro [Internet]. Jakarta: Badan Penelitian dan Pengembangan Kesehatan, Kementerian Kesehatan Rl; 2012. Available from: https://www.scribd.com/doc/142716339/Buku-Seri-Etnografi-Kesehatan-Ibu-dan-Anak-2012-Etnik-Madura-Desa-Jrangoan-Kecamatan-OmbenKabupaten-Sampang-Provinsi-Jawa-Timur

26. Laksono AD, Wulandari RD. Determinant of the Puskesmas Utilization in Madura Island. Indian J Public Heal Res Dev. 2019;10(11):576-81.

27. National Institute of Health Research and Development of the Ministry of Health of the Republic of Indonesia. The 2018 Public Health Development Index [Internet]. Jakarta; 2019. Available from: https://www.litbang.kemkes.go.id/buku-ipkm-2018/

28. National Institute of Health Research and Development. The 2013 Public Health Development Index (Indeks Pembangunan Kesehatan Masyarakat Tahun 2013). Jakarta: The Ministry of Health of Indonesia; 2014.

29. Susilowati D, Joko S, Pramuja RA. Quality Study of Human Development and Poverty in Madura Island. J Ekon Pembang. 2019;17(2):175-85.

30. Laksono AD, Ibad M, Mursita A, Kusrini I, Wulandari RD. Characteristics of mother as predictors of stunting in toddler. Pakistan J Nutr. 2019;18(12):11016.

31. Wulandari RD, Laksono AD. Education as predictor of the knowledge of pregnancy danger signs in Rural Indonesia. Int J Innov Creat Chang. 2020;13(1):1037-51.

32. Wulandari RD, Laksono AD. Determinants of knowledge of pregnancy danger signs in Indonesia. PLoS One. 2020;15(5):Article number e0232550.

33. Desbouys L, Méjean C, De Henauw S, Castetbon K. Socio-economic and cultural disparities in diet among adolescents and young adults: A systematic review. Public Health Nutr. 2020;23(5):843-60.

34. Birru SM, Belew AK, Tariku A. One in three adolescent schoolgirls in urban northwest Ethiopia is stunted. Ital J Pediatr. 2018;44(1):Article number 32.

35. Sasongko EPS, Ariyanto EF, Indraswari N, Rachmi CN, Alisjahbana A. Determinants of adolescent shortness in Tanjungsari, West Java, Indonesia. Asia Pac J Clin Nutr. 2019;28:S43-50.

36. Leroy JL, Ruel M, Sununtnasuk C, Ahmed A. Understanding the determinants of adolescent nutrition in Bangladesh. Ann N Y Acad Sci. 2018;1416(1):1830 .

37. Madjdian DS, Azupogo F, Osendarp SJM, Bras H, Brouwer ID. Socio-cultural and economic determinants and consequences of adolescent undernutrition and micronutrient deficiencies in LLMICs: a systematic narrative review. Ann N Y Acad Sci. 2018;1416(1):117-39.

38. Singh JK, Acharya D, Gautam S, Adhikari M, Park J-H, Yoo S-J, et al. Socio-demographic and diet-related factors associated with insufficient fruit and vegetable consumption among adolescent girls in rural communities of southern Nepal. Int J Environ Res Public Health. 2019;16(12):Article number 2145.

39. Harding KL, Aguayo VM, Webb P. Trends and correlates of overweight among pre-school age children, adolescent girls, and adult women in south Asia: An analysis of data from twelve national surveys in six countries over twenty years. Nutrients. 2019;11(8):Article number 1899.

40. Choudhuri D, Balaram S. Factors Associated with Nutritional Status of Adolescent Schoolchildren in Tripura. Indian Pediatr. 2020;57(2):177-8. 